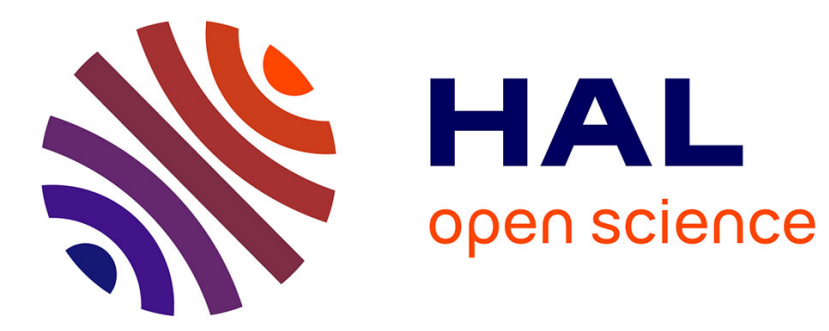

\title{
What about the circular economy of vehicles in the U.S.? An extension of the analysis done in the EU by Saidani et al. (2017)
}

Michael Saidani, Alissa Kendall, Bernard Yannou, Yann Leroy, François Cluzel

\section{- To cite this version:}

Michael Saidani, Alissa Kendall, Bernard Yannou, Yann Leroy, François Cluzel. What about the circular economy of vehicles in the U.S.? An extension of the analysis done in the EU by Saidani et al. (2017). Resources, Conservation and Recycling, 2018, 136, pp.287-288. hal-01790056

\section{HAL Id: hal-01790056 https://hal.science/hal-01790056}

Submitted on 11 May 2018

HAL is a multi-disciplinary open access archive for the deposit and dissemination of scientific research documents, whether they are published or not. The documents may come from teaching and research institutions in France or abroad, or from public or private research centers.
L'archive ouverte pluridisciplinaire HAL, est destinée au dépôt et à la diffusion de documents scientifiques de niveau recherche, publiés ou non, émanant des établissements d'enseignement et de recherche français ou étrangers, des laboratoires publics ou privés. 
To cite this article: Michael Saidani, Alissa Kendall, Bernard Yannou, Yann Leroy, François Cluzel, What about the circular economy of vehicles in the U.S.? An extension of the analysis done in the EU by Saidani et al. (2017), Resources, Conservation and Recycling, Volume 136, September 2018, Pages 287-288, https://doi.org/10.1016/j.resconrec.2018.05.007.

\title{
WHAT ABOUT THE CIRCULAR ECONOMY OF VEHICLES IN THE U.S.? AN EXTENSION OF THE ANALYSIS DONE IN THE EU BY SAIDANI ET AL. (2017)
}

\author{
Authors' names and affiliations: Michael Saidani ${ }^{1}$, Alissa Kendall ${ }^{2}$, Bernard Yannou ${ }^{1}$, Yann Leroy ${ }^{1}$, François Cluzel ${ }^{1}$ \\ 'Laboratoire Genie Industriel, CentraleSupélec, Université Paris-Saclay, France \\ ${ }^{2}$ Department of Civil and Environmental Engineering, University of California, Davis, USA \\ Contact author: michael.saidani@centralesupelec.fr \\ Published in: Resources, Conservation and Recycling as a Perspective Paper in 2018.
}

Automobile ownership worldwide has exceeded 1 billion since 2010, and the U.S. plus the EU account for $50 \%$ of this total (Sakai et al. 2014). According to Wilson (2017), CEO of the U.S. Automotive Recyclers Association (ARA): "Different countries are on different parts of the path related to end-of-life management of vehicles. By looking at how other countries deal with their industry, one can choose some parts of the path that are desirable and try to avoid some of the paths that are unpleasant." It is with this perspective that this communication initiates a discussion of the appropriate transfers and applications of recommended practices and know-how from one industrial sector (the automotive sector) to another (the heavy-duty and off-road (HDOR) sector) and from a geographic region (the EU) to another (the U.S.). Saidani et al. (2017) discussed the best industrial practices and remaining challenges for a circular economy (CE) of light and heavy vehicles in the EU. The end-of-life (EoL) business practices and regulations imposed on these sectors in the EU are considerably different than the same sectors in the U.S., and thus provide an interesting comparison case. To develop this juxtaposition, an updated literature review as well as industrial field investigations were done in the U.S. with the aim of providing supplementary insights to the questions raised by Saidani et al. (2017), including: (i) to what extent is CE achieved and implemented in the automotive and HDOR sectors, (ii) what industrial practices and regulations are prevalent and supportive of CE goals, and (iii) what are the main challenges both regions have to face for an enhanced CE of EoL vehicles?

The primary difference between these two regions lies in their regulatory frameworks. In the EU, automobile recycling targets are established through the Directive 2000/EC/53, which sets a minimum of $85 \%$ for reuse plus recovery and $95 \%$ for reuse plus recycle. European automotive manufacturers and importers are responsible for recycling costs under the Extended Producer Responsibility (EPR) principle. As a result, the EoL processing of the automotive sector is increasingly well-organised in the EU (Saidani et al. 2017). This European Directive concerns the automotive sector only, and thus the EoL management of HDOR vehicles is less developed. In the U.S., there are neither national regulations nor quantitative recycling targets for the disposal of light or heavy vehicles. The recycling of end-of-life vehicles (ELV) is only managed under crosssector regulations on environmental protection (Sakai et al. 2014). In the meantime, the European experience has demonstrated the success of law-making to encourage the reuse of automotive parts, and its associated remanufacturing and recycling markets. The latest European example can be found in France where automotive repair shops are mandated to offer clients, whenever possible, the choice between spare parts coming from CE loops and originally manufactured parts. Legislation is therefore a key action lever to enter EoL vehicles components into appropriate circularity loops.

On this basis, some organizations in the U.S. are working to make progress with legislation to change attitudes towards more responsible and sustainable practices. The National Stewardship Action Council (NSAC) is acting in speeding up the process of creating new laws to both support EPR and provide a CE in the U.S. However, according to the NSAC, no new American legislation related to the EoL management of vehicles is ongoing. In fact, it needs active industry involvement - both from producers and recycling centers - before considering legislative proceedings. Wilson (2017) confirms that the current U.S. political administration is not really pledging for new environmental regulations and automakers still fear the use of second-hand parts will lower their economic benefits. Nevertheless, the ARA is still advocating in front of U.S. Congress members to take the regulation process forward. Meanwhile, when political actions are neither proactive nor supportive, closing-the-loop has to be motivated by other considerations, such as economic ones. For instance, the embracement of circular practices by automotive manufacturers could generate billions of additional revenue (Accenture, 2016). Yet, the main challenges are: (i) to make U.S. automakers aware of economic opportunities offered by circular practices, and (ii) to assist them in their transition towards more circular businesses. Particularly, the U.S. automotive industry could take inspiration not only from European automotive actors but also from their own HDOR sector.

HDOR producers, well aware of the remaining value of their used equipments, offer a growing number of remanufactured HDOR equipment as a part of their aftermarket product services. For example, the HDOR equipment company Caterpillar is leading the way by producing both new and remanufactured HDOR equipment in the U.S. and worldwide, through a wide network of collaborators and reverse logistics. Incentives such as a deposit scheme and voluntary take-back of products ensure that large quantities of parts are returned to Caterpillar. In Europe a similar story can be told but in the light-duty sector. The French automaker Renault has developed collaborations with third parties to design an efficient circular supply chain supporting 
To cite this article: Michael Saidani, Alissa Kendall, Bernard Yannou, Yann Leroy, François Cluzel, What about the circular economy of vehicles in the U.S.? An extension of the analysis done in the EU by Saidani et al. (2017), Resources, Conservation and Recycling, Volume 136, September 2018, Pages 287-288, https://doi.org/10.1016/j.resconrec.2018.05.007.

closed-loop reused, remanufacturing and recycling of end-of-life vehicles, both to comply with the ELV Directive and to achieve sustainable profits (Saidani et al. 2017). In the U.S., the State of California is trying to develop and implement sound practices in terms of ELV management, operating state-of-the-art and licensed recycling facilities (SCADA, 2017).

Nonetheless, both regions could perform better from a CE perspective. Actually, the U.S. and the EU are facing similar challenges to achieve an enhanced circularity of their ELV. For instance, in France - with more than 1,650 authorized treatment facilities (ATFs) - 1.1 million ELV are properly and legally recovered by ATFs over the 1.8 million produced each year. In California - with 1,100 licensed dismantlers - 1.2 million vehicles reach annually the end of their useful lives, among which $30 \%$ of all are being processed through unlicensed dismantlers. The gap between deregistered cars and ELV entering in ATFs is therefore not negligible. The SCADA (2017) blames an "underground economy" of unregulated dismantlers that do not have the same environmental regulatory requirements, insurance obligations, and tax liability as required for licensed dismantlers. This unfair competition leads many licensed operators out of business. For instance, in California, the number of licensed dismantlers has declined from 1236 to 1072, between 2011 and 2016. To address this issue, the SCADA urges for better cooperation between key stakeholders in the automotive industry. Likewise, tons of ELV leak from European end-of-life channels, to be exported to Eastern Europe or North Africa where infrastructures to handle, dismantle and recycle ELV are underdeveloped. As such, Sakai et al. (2014) suggest that "a global consensus on the rules for ELV management systems at an international level" should be set up.

Another obstacle for better circularity of parts from ELV is the inconsistent access to standardized data for the EoL actors. The access to the OEMs' information on vehicle parts is indeed essential for automotive recycling businesses to put back on the market the right parts at the right prices. The European Commission has already pinpointed this challenge, stating that "information on all parts of the vehicle shall be made available in a database easily accessible to independent operators". While the HDOR actors are actually implementing measures in this regard, the ARA advocates for similar actions within the U.S. automotive sector, whether by regulations setting or by cooperation between OEMs and end-of-life third parties. The Heavy Duty (HD) Distribution Association and HD Manufacturer Association are creating product data standards for the HDOR aftermarket, involving manufacturers, distributors, and maintenance centers. By streamlining aftermarket product data, the communication about product attributes will be improve across the HD aftermarket, resulting in getting the right part more effectively for end-customers and thus fostering remanufacturing and reuse of components, critical elements for advancing CE.

To conclude, it has been found that the CE of vehicles in the EU is mainly driven and stimulated by the ELV Directive, forcing industrial automakers to cooperate with end-of-life third parties to meet the mandatory recovery, reuse and recycling targets. In contrast, progress towards an augmented circularity of vehicles in the U.S. is pushed less consistently by individual associations advocating for a CE. While the EU appears to be a few steps ahead of policy activity regarding the management of ELV, the U.S. HDOR sector presents some aspirational industrial practices, e.g. collaboration between HDOR aftermarket actors or the Caterpillar example. As such, to move towards a truly circular eco-system, we highlight the importance of not only a proper regulatory framework but also a common vision and shared commitment between all stakeholders concerned in the (re)use of automotive parts and HDOR equipments. Also, newly industrialized countries such as China, India, or Brazil - where the number of vehicles reaching their EoL will soon outnumber the European or American figures should be a focus of interest and research. In this light, we believe it is of the utmost significance for them to anticipate obstacles and to take inspiration from the best political, industrial and business practices in both the EU and U.S. to innovate towards even more effective management of their ELV.

\section{Acknowledgements:}

We are grateful for the discussions we had with individuals from the following U.S organizations: the Automotive Recyclers Association, the National Stewardship Action Council, the Californian Product Stewardship Council, Caterpillar and Holt of California. We thank them all for their precious time and insights. Also, we would like to acknowledge the support of the Fulbright Commission and the Institute of International Education to make possible this study through a research collaboration between the University of California-Davis, in the USA, and CentraleSupelec, Université Paris-Saclay, in France.

\section{References:}

Accenture, 2016. "Automotive's Latest Model: Redefining Competitiveness through the Circular Economy," Report. Available online (1 April 2018): https://www.accenture.com/us-en/insight-redefining-competitiveness-through-circular-economy

Saidani, M., Yannou, B., Leroy, Y., Cluzel, F., 2017. "Heavy vehicles on the road towards the circular economy: Analysis and comparison with the automotive industry", Resources, Conservation and Recycling, doi:10.1016/j.resconrec.2017.06.017

Sakai, S., Yoshida, H., Hiratsuka, J. et al. 2014. "An international comparative study of end-of-life vehicle (ELV) recycling systems", J Mater Cycles Waste Manag, 16/1.

SCADA-State of California Auto Dismantlers Association, 2017. "The Underground Economy", Report and Recommendations. 
To cite this article: Michael Saidani, Alissa Kendall, Bernard Yannou, Yann Leroy, François Cluzel, What about the circular economy of vehicles in the U.S.? An extension of the analysis done in the EU by Saidani et al. (2017), Resources, Conservation and Recycling, Volume 136, September 2018, Pages 287-288, https://doi.org/10.1016/j.resconrec.2018.05.007.

Wilson, M., 2017. "Key to the concept - Automotive manufacturers must embrace parts reuse because it is key to the industry's circular economy." Recycling Today, August 31, 2017. Available online (1 April 2018): http://www.recyclingtoday.com/article/automotive-parts-reuse/ 